\title{
Combination of ICP-MS, capillary electrophoresis, and their hyphenation for probing Ru(III) metallodrug-DNA interactions
}

\author{
Lidia S. Foteeva ${ }^{1} \cdot$ Magdalena Matczuk $^{2} \cdot$ Katarzyna Pawlak $^{2} \cdot$ Svetlana S. Aleksenko $^{3}$. \\ Sergey V. Nosenko ${ }^{4}$. Vasily K. Karandashev ${ }^{4}$ Maciej Jarosz ${ }^{2} \cdot$ Andrei R. Timerbaev $^{1}$
}

Received: 7 November 2016/Revised: 25 December 2016/Accepted: 3 January 2017 /Published online: 23 January 2017

(C) The Author(s) 2017. This article is published with open access at Springerlink.com

\begin{abstract}
Determination of the DNA-binding reactivity and affinity is an important part of a successful program for the selection of metallodrug candidates. For such assaying, a range of complementary analytical techniques was proposed and tested here using one of few anticancer metal-based drugs that are currently in clinical trials, indazolium trans-[tetrachloridobis( $1 H$-indazole)ruthenate(III), and a DNA oligonucleotide. A high reactivity of the Ru drug was confirmed in affinity capillary electrophoresis (CE) mode, where adduct formation takes place in situ (i.e., in the capillary filled with an oligonucleotide-containing electrolyte). To further characterize the binding kinetics, a drug-oligonucleotide mixture was incubated for a different period of time, followed by ultrafiltration separation into two different in molecular weight fractions ( $>3$ and $<3 \mathrm{kDa}$ ). The time-dependent distribution profiles of the Ru drug were then assessed by CEinductively coupled plasma mass spectrometry (ICP-MS), revealing that at least two DNA adducts exist at equilibrium
\end{abstract}

Electronic supplementary material The online version of this article (doi:10.1007/s00216-017-0186-0) contains supplementary material, which is available to authorized users.

Magdalena Matczuk

mmatczuk@ch.pw.edu.pl

1 Vernadsky Institute of Geochemistry and Analytical Chemistry, Kosygin St. 19, 119991 Moscow, Russian Federation

2 Chair of Analytical Chemistry, Faculty of Chemistry, Warsaw University of Technology, Noakowskiego St. 3, 00-664 Warsaw, Poland

3 Saratov State University, Astrakhanskaya St. 83, 410012 Saratov, Russian Federation

4 Institute of Microelectronics Technology and High-Purity Materials, Acad. Ossipyan St. 6, 142432 Chernologolovka, Russian Federation conditions. Using standalone ICP-MS, dominant equilibrium amount of the bound ruthenium was found to occur in a fraction of $5-10 \mathrm{kDa}$, which includes the oligonucleotide (ca. $6 \mathrm{kDa}$ ). Importantly, in all three assays, the drug was used for the first time in in-vitro studies, not in the intact form but as its active species released from the transferrin adduct at simulated cancer cytosolic conditions. This circumstance makes the established analytical platform promising to provide a detailed view on metallodrug targeting, including other possible biomolecules and ex vivo samples.

Keywords Anticancer metallodrugs · DNA $\cdot$ ICP-MS · Capillary electrophoresis

\section{Introduction}

Anticancer metallodrugs seem to have a great many targets such as DNA, proteins, membranes, etc. However, the true lesion responsible for the biological activity of a drug is difficult to determine. This is not only because metal complexes are naturally diversely reactive species. There are at least two additional obstacles. First, analytical techniques and tools being used to map interactions with different pertinent biomolecules are not always of the metallomic origin and, as such, incapable to identify, characterize, and quantify metal species stemmed from binding. Then the path taken by a metal complex in reaching its target and accompanying changes in metal speciation are typically downplayed.

In an attempt to resolve these challenges, the present study was designed around an experimental anticancer rutheniumbased drug, indazolium trans-[tetrachloridobis $(1 \mathrm{H}$ indazole)ruthenate(III), and DNA, representing a fruitful target for metal complexes [1-3]. The selection of this metallodrug was governed not only by the advanced status 
of its development $[4,5]$ but also by a great deal of accumulated knowledge regarding the chemistry behind a drug's delivery, uptake, and cell processing, including activation and targeting [6-9]. While DNA is thought to be not the main target for this (as well as any other) Ru drug [10, 11], no other cell component is unambiguously proven to play this role. To simplify the metal-bio system under scrutiny, a DNA oligonucleotide rich of GMP, the major nucleotide binding metallodrugs (including the ruthenium drug of interest [12, 13]), was employed in binding experiments (as a DNA sequence simpler than the more heterogeneous genomic DNA).

In a basic metallomic approach, a highly sensitive metalspecific method, inductively coupled plasma mass spectrometry (ICP-MS), is used in on-line combination with a highthroughput separation technique. Capillary electrophoresis (CE) constitutes a powerful method to resolve mixtures of metallodrugs, their metabolites, and adducts with biomolecules, including DNA binding blocks (such as GMP [12, 13]), prior to ICP-MS detection [14-16]. In situations where more accurate binding information is requested, ICP-MS quantification following fractionation of a drug-biomolecule mixture by ultrafiltration is preferable [17] (though at the expense of on-line configuration). Whichever individual metallomic (or complementary) technique is in use, their combined application would help gain a deeper understanding of biotransformations for a given complex. This strategy was adopted here to develop a versatile analytical platform for characterization of different metallodrug-DNA systems.

\section{Materials and methods}

\section{Materials}

The lyophilized powder of DNA oligonucleotide (5'- GTC GTA CTG ATA CAT GAG CC -'3; $6117 \mathrm{Da}$ ) was the product of Genomed (Warsaw, Poland) or Syntol (Moscow, Russia). It was used as an aqueous solution prepared in accordance with the producer recommendations and stored at $-20^{\circ} \mathrm{C}$ no longer than 1 month. Indazolium trans-[tetrachloridobis $(1 H-$ indazole)ruthenate(III)] was synthesized at the University of Vienna (see the Electronic Supplementary Material (ESM) for chemical formula). The stock solution of the Ru drug (1 mM) was prepared daily in $100 \mathrm{mM} \mathrm{NaCl}$. Human transferrin (>98\%), glutathione (>98\%), and L-ascorbic acid (>99.5\%) were purchased from Sigma-Aldrich (St. Louis, USA). Sodium chloride, sodium dihydrogen phosphate, disodium hydrogen phosphate, also from Sigma-Aldrich (St. Louis, USA), were of analytical reagent grade. Sodium hydroxide and citric acid (>99.5\%) were obtained from Fluka (Buchs, Switzerland). High-purity water $\left(18 \mathrm{M} \Omega \mathrm{cm}^{-1}\right)$ used throughout this work was obtained from a Milli-Q water purification system (Millipore Elix 3; Saint-Quentin, France).

\section{Instrumentation}

A X-7 Thermo Elemental and an Agilent 7500a mass spectrometers were used for off-line and hyphenated ICP-MS measurements, respectively. In case of standalone operation, the instrument was equipped with a standard lowvolume glass spray chamber (Peltier, cooled at $3{ }^{\circ} \mathrm{C}$ ), and a concentric glass PolyCon nebulizer operating at a sample uptake rate of $0.8 \mathrm{~mL} \mathrm{~min}^{-1}$. Before analysis, the instrument was tuned to achieve maximum sensitivity and ${ }^{115}$ In served as internal standard. For coupling to $\mathrm{CE}$, a torch with a smaller inlet $(1.5 \mathrm{~mm})$ was utilized to minimize the influence of plasma backpressure on the electrophoretic flow, and a platinum shield was installed into the torch to improve sensitivity. Fitted with a microconcentric nebulizer CEI-100 (CETAC, Omaha, NE, USA), the mass spectrometer was interfaced with an Agilent $\mathrm{HP}^{3 \mathrm{D}} \mathrm{CE}$ system (Waldbronn, Germany). Affinity CE was performed using a CAPEL 105 (Lumex, St. Petersburg, Russia).

Fused-silica capillaries of inner diameter of $75 \mu \mathrm{m}$ and total length as specified below were obtained from CM Scientific Ltd. (Silsden, UK) or BGB Analytik (Schlossboeckelheim, Germany). Prior to the first use, the capillary was flushed at 1 bar with $1 \mathrm{M} \mathrm{NaOH}$ and water (30 min each). The capillary cassette and sample tray were thermostatted at $37^{\circ} \mathrm{C}$. Samples were introduced into the capillary hydrodynamically. A high voltage with a positive polarity placed at the inlet end of the capillary was applied to generate separations. Instrument control and data analysis were performed using ChemStation (Agilent) or Elforan (Lumex) software. The main instrumental and operational parameters are presented in Table 1.

A Bandelin Sonorex ultrasonic bath (model 1210; Walldorf, Germany) was used for degassing the solutions. Samples were incubated at $37{ }^{\circ} \mathrm{C}$ in a WB 22 (Memmert, Schwabach, Germany) or a TC-150 (Brookfield, Middleboro, USA) thermostat. For ultrafiltration experiments, a MPW-350R (JW Electronic, Warsaw, Poland) or a CM$50 \mathrm{M}$ (ELMI Ltd., Riga, Latvia), operating at 10,000 and 1000-10,000 rpm, respectively, and different molecular mass cut-off filters (Amicon Ultracel; Millipore, Molsheim, France) were employed.

\section{Sample preparation}

A workflow template for sample handling is presented in Fig. 1. An aliquot of drug stock solution was mixed with $5 \times 10^{-5} \mathrm{M}$ solution of transferrin in $10 \mathrm{mM}$ phosphate buffer, $\mathrm{pH} 7.4$, containing $100 \mathrm{mM} \mathrm{NaCl}$, to give a 2-fold molar excess of the drug over the protein in the final solution. The resultant mixture was incubated for $3 \mathrm{~h}$ at $37^{\circ} \mathrm{C}$ to ensure complete adduct formation [18] and then ultrafiltrated through a $10 \mathrm{kDa}$ cut-off filter for $30 \mathrm{~min}\left(37^{\circ} \mathrm{C}\right)$ to isolate the adduct. After reverse ultrafiltration, the adduct solution 
Table 1 Operational parameters and settings

\begin{tabular}{|c|c|c|}
\hline ICP-MS & Standalone & Hyphenated \\
\hline Plasma gas flow rate & $12 \mathrm{~L} \mathrm{~min}^{-1}$ & $15 \mathrm{~L} \mathrm{~min}^{-1}$ \\
\hline Auxiliary gas flow rate & $0.9 \mathrm{~L} \mathrm{~min}^{-1}$ & $0.9 \mathrm{~L} \mathrm{~min}^{-1}$ \\
\hline Plasma rf power & $1250 \mathrm{~W}$ & $1290 \mathrm{~W}$ \\
\hline Isotopes monitored & ${ }^{101} \mathrm{Ru},{ }^{102} \mathrm{Ru},{ }^{115} \mathrm{In}$ & ${ }^{102} \mathrm{Ru},{ }^{57} \mathrm{Fe}$, \\
\hline Dwell time & $1 \mathrm{~ms}$ & $100 \mathrm{~ms}$ \\
\hline \multicolumn{3}{|l|}{ Interface } \\
\hline $\begin{array}{l}\text { Spray chamber } \\
\text { volume }\end{array}$ & $5 \mathrm{~mL}$ & \\
\hline $\begin{array}{l}\text { Nebulizer gas flow } \\
\text { rate }\end{array}$ & $1.0 \mathrm{~L} \mathrm{~min}^{-1}$ & \\
\hline \multicolumn{3}{|l|}{$\mathrm{CE}$} \\
\hline Capillary & $\begin{array}{l}\text { Fused-silica, inner diameter } \\
75 \mu \mathrm{m} \text {, length } 70 \mathrm{~cm}\end{array}$ & \\
\hline BGE & $\begin{array}{l}10 \mathrm{mM} \mathrm{NaH}_{2} \mathrm{PO}_{4}-10 \mathrm{mM} \\
\quad \mathrm{Na}_{2} \mathrm{HPO}_{4}, 4 \mathrm{mM} \mathrm{NaCl}, \mathrm{pH} 6.0\end{array}$ & \\
\hline Sample introduction & $\begin{array}{l}30 \mathrm{mbar} \text { for } 10 \mathrm{~s} \text { (injection volume } \\
25.5 \mathrm{~nL} \text { ) }\end{array}$ & \\
\hline Voltage & $25 \mathrm{kV}$ & \\
\hline Current & $28-32 \mu \mathrm{A}$ & \\
\hline Sheath liquid & $\begin{array}{c}1 \mathrm{mM} \text { phosphate buffer (pH 6.0) } \\
0.4 \mathrm{mM} \mathrm{NaCl}, 20 \mu \mathrm{g} \mathrm{L}^{-1} \mathrm{Ge}\end{array}$ & \\
\hline \multicolumn{3}{|l|}{ Affinity CE } \\
\hline Capillary & $\begin{array}{l}\text { Fused-silica, inner diameter } \\
\quad 75 \mu \mathrm{m} \text {, length } 60 / 50.5 \mathrm{~cm}\end{array}$ & \\
\hline BGE & $\begin{array}{l}10 \mathrm{mM} \mathrm{NaH}_{2} \mathrm{PO}_{4}-10 \mathrm{mM} \\
\quad \mathrm{Na}_{2} \mathrm{HPO}_{4}, 4 \mathrm{mM} \text { NaCl, pH 6.0 } \\
2 \times 10^{-5} \mathrm{M} \text { oligonucleotide }\end{array}$ & \\
\hline Sample introduction & 10 mbar for $5 \mathrm{~s}(4 \mathrm{~nL})$ & \\
\hline Voltage & $10 \mathrm{kV}$ & \\
\hline Current & $47 \mu \mathrm{A}$ & \\
\hline
\end{tabular}

$(\sim 30 \mu \mathrm{L})$ was mixed with a solution mimicking cancer cell cytosol, to give a final adduct concentration of $5 \times 10^{-5} \mathrm{M}$. The cytosol solution comprised $10 \mathrm{mM}$ phosphate buffer (pH 6.0), $4 \mathrm{mM} \mathrm{NaCl}$, glutathione (10 $\mathrm{mM})$, ascorbic acid $(10 \mathrm{mM})$, and citric acid $(100 \mathrm{mM})$. The mixture was incubated for $24 \mathrm{~h}$ and then ultrafiltrated through a $10 \mathrm{kDa}$ filter for $40 \mathrm{~min}$. The ultrafiltrate was introduced into the capillary filled with $10 \mathrm{mM}$ phosphate buffer $(\mathrm{pH} 6.0)$, containing $4 \mathrm{mM} \mathrm{NaCl}$ and $2 \times 10^{-7}-2 \times 10^{-5} \mathrm{M}$ DNA oligonucleotide (ACE), or mixed with the DNA oligonucleotide solution (final concentration of oligonucleotide $2 \times 10^{-6} \mathrm{M}$ ). The mixture was incubated at $37^{\circ} \mathrm{C}$ and aliquots were taken at a specified time (only after $24 \mathrm{~h}$ for ICP-MS) for ultrafiltration (40 min). A consecutive ultrafiltration with different combinations of filters was then performed. In the case of CE-ICP-MS, the initial ultrafiltrate was filtrated through a $30 \mathrm{kDa}$ filter and the obtained ultrafiltrate through a $3 \mathrm{kDa}$ filter, and both fractions (3-30 and $<3 \mathrm{kDa}$ ) were analyzed.
For off-line ICP-MS, the ultrafiltration sequence was a three-step in an order of 10,5 , and $3 \mathrm{kDa}$ filter, following an appropriate dilution of $\mathrm{Ru}-\mathrm{DNA}$ mixture with $2.5 \%$ nitric acid, so that the four fractions were subject to analysis.

\section{Results and discussion}

\section{Intracellular activation of ruthenium drug}

As a matter fact, among drug developers there is still no consensus regarding the mechanism of uptake and activation of the ruthenium drug of interest $[10,11]$. According to the most often quoted concept of transportation, the drug enters the cell via transferrin route, being bound to this protein (though not the main binding partner in the bloodstream). The second popular hypothesis implies that within cancer cell the drug is activated to more reactive species, most likely by detaching transferrin and reduction to some $\mathrm{Ru}(\mathrm{II})$ species. A recent systematic study carried out in our laboratories focused on intracellular activation chemistry of a given Ru drug, including cancer cytosol environment [18-20]. Using a multidimensional metallomic approach, the evolution of a number of low molecular weight (MW) Ru species was ascertained, in which glutathione and ascorbic acid as the major bioreductants have a dominant impact on the drug-transferrin adduct. While the identification of ruthenium species bears so far a tentative character, this is not a constraint for the current investigation. Therefore, for consistency we have used here the same adduct formation and activation protocol as before (see Sample preparation section).

\section{Affinity CE}

When affinity CE (ACE) is the method of choice, chemical processes comprising a metallodrug (as well as any other charged or under certain conditions, uncharged species) can be differentiated kinetically with regard to the time scale of a typical CE run (tens of minutes) [21, 22]. Rather fast reactions between the drug and a selected component of the background electrolyte (e.g., a bioligand) essentially attain the equilibrium during the time for which the drug stays in the capillary (more strictly speaking, is transported past the detector), giving rise to a binding response. With direct photometric detection, it can be displayed as two novel signals: a peak of the drug-bioligand adduct and a dip-peak attributable to a drop in the bioligand concentration (for a detailed view of all possible response scenarios, see ESM, Fig. S1). Otherwise, for fairly slow binding processes, one can expect no binding response (but only the free drug peak). Notably, such reactions are not discriminated against the $\mathrm{CE}$ assaying but passed to the realm of ordinary $\mathrm{CE}$ 


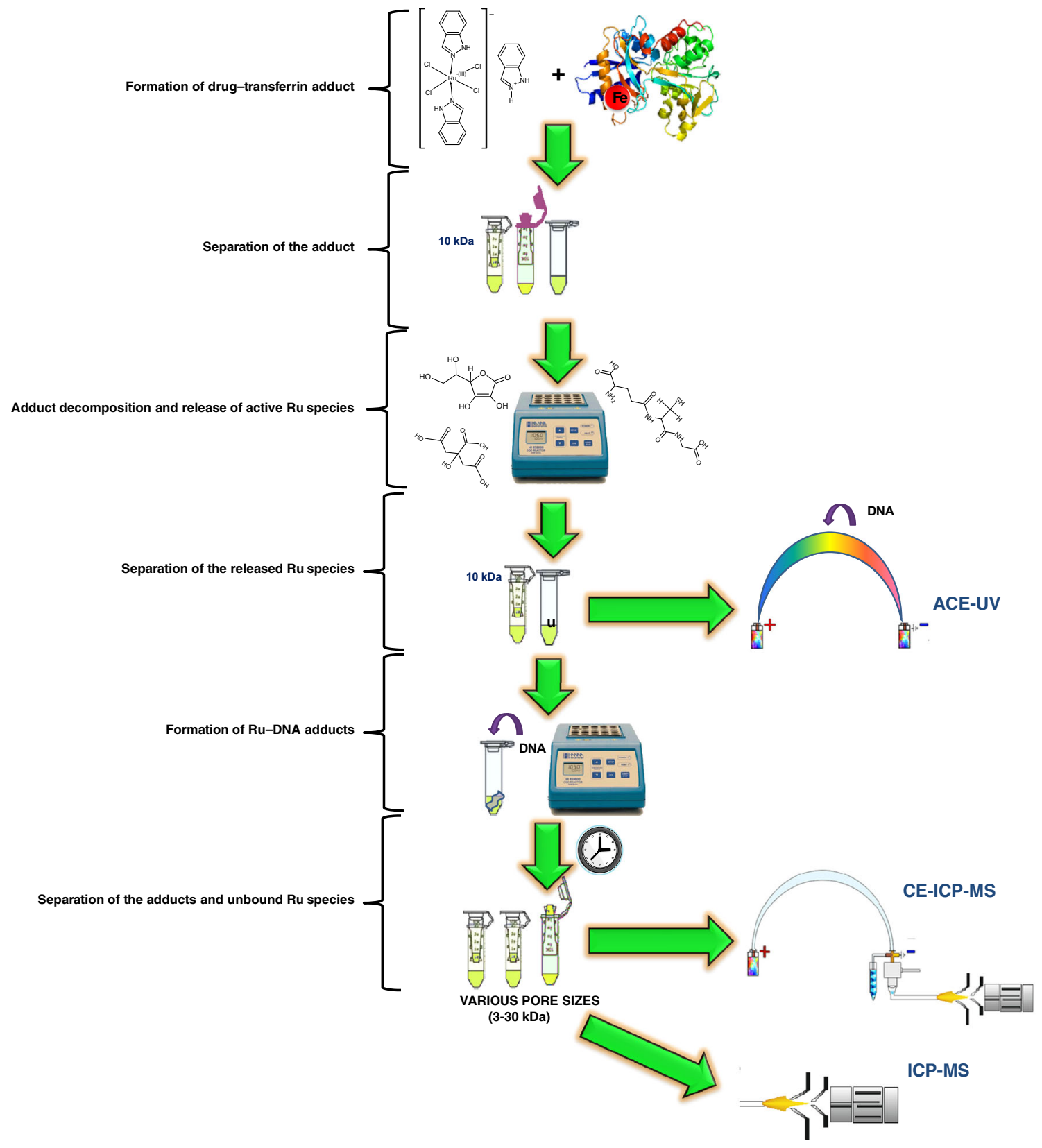

Fig. 1 Analytical protocol for formation, isolation, and three-dimensional analysis of Ru-DNA species

mode (using incubation of the reaction mixture for a certain period of time prior to analysis) [21].

It is important to point out that ACE analysis of chemical equilibria in metallodrug-bioligand systems has not yet become an accepted practice. Binding to proteins is known to proceed with comparatively slow kinetics (see [21] for a summary of kinetic data). For DNA, no published accounts on its interaction with metal-based drugs assessed by ACE can be traced in the literature. However, there are at least two reports by the group of Kane-Maguire and Wheeler [23, 24] indicative of that interactions between the metal complexes and DNA may be fast enough to exhibit a binding response in ACE. When DNA has been used in the electrophoretic buffer, resolution of the transition metal complexes into their optical isomers was observed. Such enantioselective effect can be explained by differences in isomer binding affinity toward DNA.

In order to simulate cancer cytosol electrolyte conditions, $10 \mathrm{mM}$ phosphate buffer, $\mathrm{pH} 6.0$, containing $4 \mathrm{mM} \mathrm{NaCl}$, was chosen as a background electrolyte milieu. (We leave beyond the scope of this study the issue on the exact point where in-vivo interaction between active drug forms and DNA occurs, and cellular electrolyte settings at this point.) The DNA oligonucleotide concentration in the electrolyte was increased stepwise from $2 \times 10^{-7}$ to $2 \times 10^{-5} \mathrm{M}$. As the main parameter affecting analyte migration velocity and, inversely, the capillary residence (or 
reaction) time, the applied voltage was also subject to optimization. As a result of systematic variations in the range from 6 to $15 \mathrm{kV}$, a voltage of $10 \mathrm{kV}$, providing the optimal migration time and resolution, minimum peak broadening, acceptable running current, and also a lack of system peaks, was selected.

Upon injection of active drug forms (prepared as described above), there was no binding response at the lowest concentration of DNA, while certain changes were noticed to occur at $2 \times$ $10^{-6} \mathrm{M}$; however, peak shape, intensity, and reproducibility were unsatisfactory. On the other hand, when using a $2 \times 10^{-5} \mathrm{M}$ DNA-containing electrolyte, the ACE system yielded a reproducible binding response (Fig. 2, trace C). It should be mentioned that without incorporating DNA, two well-resolved peaks of negatively charged $\mathrm{Ru}$ species were recorded (Fig. 2, trace B). This finding is in accord with our previous results [25], showing the occurrence of two active drug forms released from the transferrin adduct in the cytosol-like solution (see also CE-ICP-MS data below). Comparing traces $\mathrm{B}$ and $\mathrm{C}$, it can be inferred that an additional peak, seen in trace $\mathrm{C}$, is due to an DNA-binding product evolved in a ca. 20-min timespan.

\section{CE-ICP-MS}

To gain further insight into the binding phenomenon, the active forms of the Ru drug were pre-incubated with oligonucleotide (up to $48 \mathrm{~h}$ ) and subsequently analyzed by CE-ICP-MS

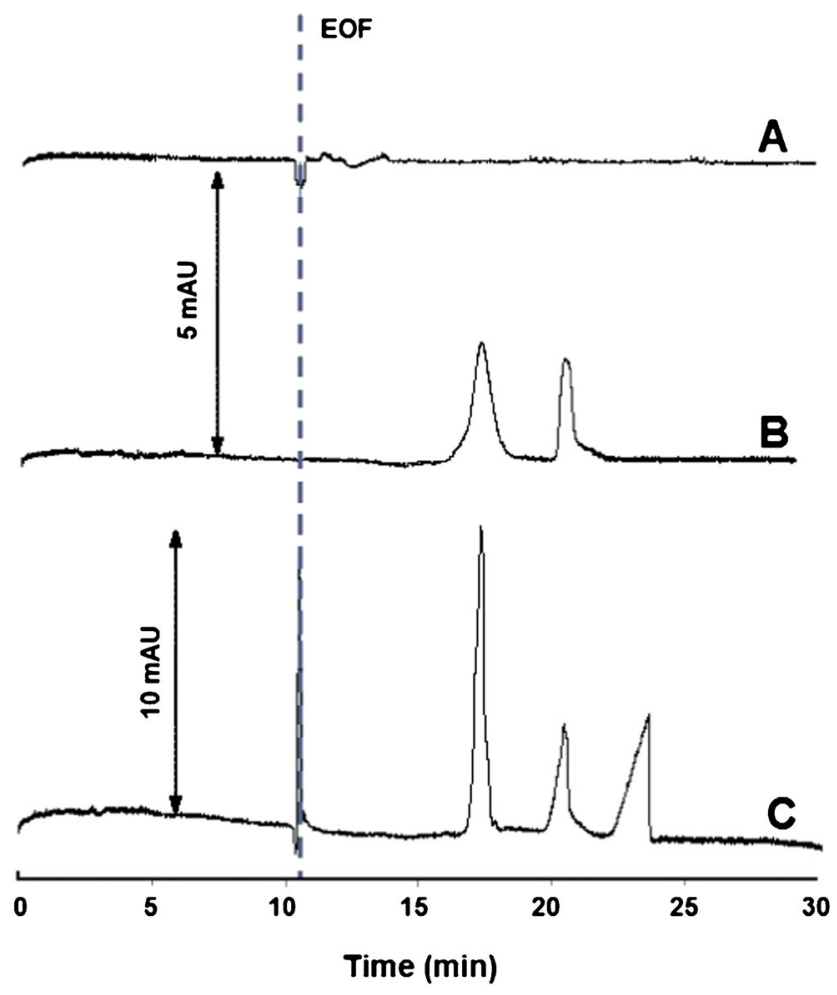

Fig. 2 Electropherograms proving Ru-DNA binding. Sample: A - water (blank analysis); B, C - drug (in active form). Concentration of DNA in electrolyte: A, C $-2 \times 10^{-5} \mathrm{M}$; B - zero. EOF = electroosmotic flow. Other ACE conditions, see Table 1

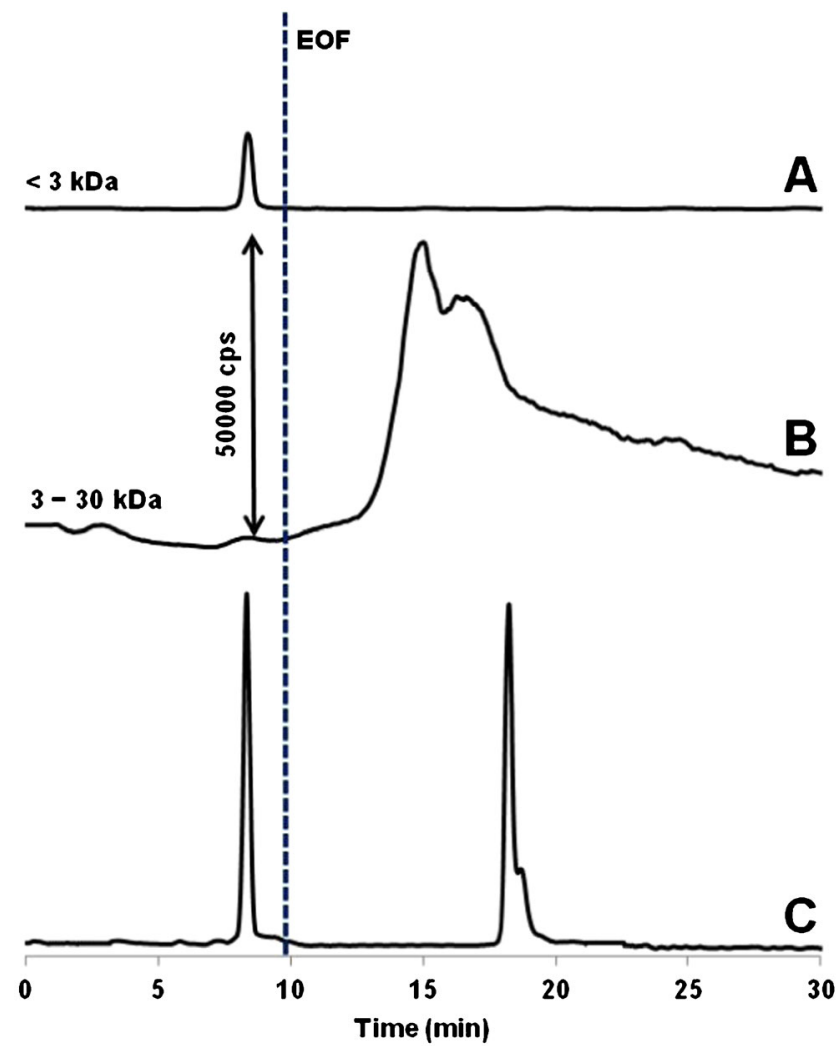

Fig. 3 Various ruthenium species constituting drug's active forms and originating from their 24-h interaction with DNA oligonucleotide. Trace $\mathrm{C}$ resulted from blank analysis (without oligonucleotide added). For $\mathrm{CE}$ and ICP-MS conditions, see Table 1

(see experimental for ultrafiltration conditions). The same electrolyte buffer system was used in these trials as in ACE but void of oligonucleotide. The prerequisite of analyzing the two fractions as exemplified in Fig. 3, was that in fraction B (3-30 kDa) we expected to detect the signals of Ru-oligonucleotide adducts, while at $\angle 3 \mathrm{kDa}$ in fraction $\mathrm{A}$ the low $\mathrm{MW}$ species of Ru could be monitored.

From Fig. 3 it is evident that at equilibrium conditions about $90 \% \mathrm{Ru}$ are converted into high MW species (for comparative reasons, Fig. S2 in the ESM shows results of the CEICP-MS analysis of the same fractions after a shorter incubation time; note that one anionic form of Ru is still detectable). Apparently these species comprise at least two oligonucleotide adducts migrating as the overlapping peaks. It is important to note that in the studies on modeling physiological conditions, the selection of CE system parameters capable to enhance the resolution is typically restricted to very few variables, such as the applied voltage in our case. With regard to notable peak broadening, this was no great surprise as DNA oligonucleotides are known to adsorb onto the fused-silica capillary wall [24].

As shown in Fig. 3, even after prolonged incubation, a low MW species of Ru remains unattached to oligonucleotide and, importantly, migrates ahead of the EOF (i.e., in the migration 
Table 2 Results of the ICP-MS analysis $(n=3 ; P=0.95)$

\begin{tabular}{lll}
\hline Fraction & Concentration of $\mathrm{Ru}\left(\times 10^{-6} \mathrm{M}\right)$ & Fraction content assignment \\
\hline$>10 \mathrm{kDa}$ & $1.0 \pm 0.1$ & Adduct(s) with a Ru-to-DNA ratio of 1:2 \\
$5-10 \mathrm{kDa}$ & $7.2 \pm 0.5$ & Mono-DNA adducts \\
$3-5 \mathrm{kDa}$ & $<\mathrm{LOQ}^{\mathrm{a}}$ & - \\
$<3 \mathrm{kDa}$ & $1.3 \pm 0.2$ & Free Ru \\
\hline
\end{tabular}

${ }^{\mathrm{a}} \mathrm{LOQ}$ : limit of quantification $\left(1.2 \times 10^{-9} \mathrm{M}\right)$. range of positively charged analytes. Very likely the respective peak seen in trace $\mathrm{A}$ is due to $\left[\mathrm{Ru}^{\mathrm{II}} \mathrm{Hind}(\mathrm{OH})\left(\mathrm{H}_{2} \mathrm{O}\right)_{3}\right]^{+}$ (Hind $=1 H$-indazole) identified as one of few (and the only cationic) ruthenium form released from the transferrin adduct under simulated cancer cytosol conditions [25] (cf., trace C). The fact that fraction A contains no negatively charged species can be inferred that non-hydrolyzed species, such as $\left[\mathrm{Ru}^{\mathrm{II}} \mathrm{HindCl}_{4}(\mathrm{GSH})\right]^{2-}$ and $\left[\mathrm{Ru}^{\mathrm{II}} \mathrm{HindCl}_{4}(\mathrm{GSSG})\right]^{2-}[25]$ (see two co-migrating peaks in trace $\mathrm{C}$ recorded in the absence of DNA), tend to interact more strongly with DNA.

\section{ICP-MS}

It is useful to note that although CE-ICP-MS proved to be highly practicable as a speciation tool [16], the technique can be insufficiently sensitive when dealing with metal-bioligand species in real samples [14]. Even though this is not the case of the present study, we considered direct ICP-MS analysis to be offering viable supplementary information since through a series of ultrafiltration steps the content of the $\mathrm{Ru}$ species could fall beyond the limit of detection of CE-ICP-MS.

Analytical measurements of ruthenium originating from its drugs can be hampered by interfering $\mathrm{m} / \mathrm{z}$ signals. A detailed investigation by Brouwers et al. showed, however, that neither ultrafiltrates, being free of proteins, nor the diluents, such as $1 \%$ nitric acid, but biological matrices cause a problem of interfering peaks at the mass-to-charge ratios of ruthenium [26]. Therefore, we have limited validation experiments on evaluation of unresolved spectral interferences to a blank (drug-free) analysis, as well as the analysis of DNA nucleotide as the only noncommercial chemical used. Both gave negligible interfering signals ( $\leq 4 \mathrm{cps}$ ). As an additional proof of no unanticipated spectral interferences, matching results were obtained by measuring ${ }^{101} \mathrm{Ru}$ and ${ }^{102} \mathrm{Ru}$ isotopes for all samples shown in Table 2.

On the other hand, it was deemed obligatory to verify that all the sample preparation steps, particularly ultrafiltration, made no substantial analyte loss (e.g., associated with the sorption onto filter membrane or a plastic device). In the ultrafiltrate obtained after the treatment of the transferrin adduct with simulated cancer-cytosol solution, the $\mathrm{Ru}$ concentration was found within $10 \%$ of the nominal value (based on initial drug amount), indicating the satisfying recovery.

Table 2 gives a summary on the ruthenium distribution between fractions different in MW. As expected, the highest
Ru level was found in the fraction bracketing the MW of DNA nucleotide (ca. $6 \mathrm{kDa}$ ). The amount of free ruthenium relative to the total amount of high MW Ru species conforms to the CE-ICP-MS data. What was less predictable, a rather high concentration of Ru exists in the fraction with the MW over $10 \mathrm{kDa}$. The most plausible explanation is that this is attributed to the formation of bis-DNA adducts.

\section{Conclusions}

In summary, the present work demonstrates a proof of principle for investigating the interaction of metal-based drugs with biological targets. With the integrated use of CE and ICP-MS techniques, the formation of adducts between the experimental $\mathrm{Ru}(\mathrm{III})$ drug (importantly, as its active species to be possibly released in cancer cytosol) and DNA oligonucleotide has been confirmed. However, the binding system utilized to illustrate this platform is quite provisional, as the drug of choice is believed to primarily attack other biostructures inside the cancer cell (e.g., proteins like GRP-78), while the DNA model system selected takes into account only some elements of the supposed in vivo situation. Yet the binding information acquired suggests that the analytical approach described above may indeed be useful for assessing the intracellular fate of metallodrugs. Subsequent efforts to use this methodology will focus on different drug-biomolecule systems under circumstances matching as much as possible a real-world situation.

Acknowledgements The authors gratefully acknowledge the financial support of Warsaw University of Technology and the Russian Foundation for Basic Research (grant no. 16-33-60230). M.M. is thankful to Łukasz Górski for donation of DNA oligonucleotide.

\section{Compliance with ethical standards}

Conflict of interest The authors declare that they have no conflict of interest.

Open Access This article is distributed under the terms of the Creative Commons Attribution 4.0 International License (http:// creativecommons.org/licenses/by/4.0/), which permits unrestricted use, distribution, and reproduction in any medium, provided you give appropriate credit to the original author(s) and the source, provide a link to the Creative Commons license, and indicate if changes were made. 


\section{References}

1. Komor AC, Barton JK. The path for metal complexes to a DNA target. Chem Commun. 2013;49(35):3617-30.

2. Ashfaq M, Najam T, Shah SSA, Ahmad MM, Shaheen S, Tabassum R, et al. DNA binding mode of transition metal complexes, a relationship to tumor cell toxicity. Curr Med Chem. 2014;21(26):3081-94.

3. Pages BJ, Ang DL, Wright EP, Aldrich-Wright JP. Metal complex interactions with DNA. Dalton Trans. 2015;44(8):3505-26.

4. Trondl R, Heffeter P, Kowol CR, Jakupec MA, Berger W, Keppler BK. NKP-1339, the first ruthenium-based anticancer drug on the edge to clinical application. Chem Sci. 2014;5(8):2925-32.

5. Bacher F, Arion VB. Ruthenium compounds as antitumor agents: New developments. In: Reedijk J, editor. Elsevier reference module in chemistry, molecular sciences, and chemical engineering. Elsevier: Waltham; 2014. p. 1-50.

6. Levina A, Mitra A, Lay PA. Recent developments in ruthenium anticancer drugs. Metallomics. 2009;1(6):458-70.

7. Gianferrara T, Bratos I, Alessio E. A categorization of metal anticancer compounds based on their mode of action. Dalton Trans. 2009;37:7588-98.

8. Antonarakis ES, Emadi A. Ruthenium-based chemotherapeutics: are they ready for prime time? Cancer Chemother Pharmacol. 2010;66(1):1-9.

9. Bergamo A, Gaiddon C, Schellens JHM, Beijnen JH, Sava G. Approaching tumor therapy beyond platinum drugs: status of the art and perspectives of ruthenium drug candidates. J Inorg Biochem. 2012;106(1):90-9.

10. Bergamo A, Sava G. Ruthenium anticancer compounds: myths and realities of the emerging metal-based drugs. Dalton Trans. 2011;40(31):7817-23.

11. Timerbaev AR. Role of metallomic strategies in developing ruthenium anticancer drugs. Trends Anal Chem. 2016;80:547-54.

12. Schluga P, Hartinger CG, Egger A, Reisner E, Galanski M, Jakupec MA, et al. Redox behavior of tumor-inhibiting ruthenium(III) complexes and effects of physiological reductants on their binding to GMP. Dalton Trans. 2006;35(14):1796-802.

13. Groessl M, Hartinger CG, Dyson PJ, Keppler BK. CZE-ICP-MS as a tool for studying the hydrolysis of ruthenium anticancer drug candidates and their reactivity towards the DNA model compound dGMP. J Inorg Biochem. 2008;102(5/6):1060-5.

14. Timerbaev AR. Capillary electrophoresis-mass spectrometry in biospeciation analysis: critical evaluation. Trends Anal Chem. 2009;28(4):416-25.
15. Timerbaev AR, Pawlak K, Aleksenko SS, Foteeva LS, Matczuk M, Jarosz M. Advances of CE-ICP-MS in speciation analysis related to metalloproteomics of anticancer drugs. Talanta. 2012;102:164-70.

16. Timerbaev AR. Element speciation analysis using capillary electrophoresis: twenty years of development and applications. Chem Rev. 2013;113(1):778-812.

17. Timerbaev AR. Recent progress of ICP-MS in the development of metal-based drugs and diagnostic agents. J Anal At Spectrom. 2014;29(6):1058-72.

18. Aleksenko SS, Matczuk M, Lu X, Foteeva LS, Pawlak K, Timerbaev AR, et al. Metallomics for drug development: an integrated CE-ICPMS and ICP-MS approach reveals the speciation changes for an investigational ruthenium(III) drug bound to holo-transferrin in simulated cancer cytosol. Metallomics. 2013;5(8):955-63.

19. Matczuk M, Prządka M, Aleksenko SS, Czarnocki Z, Pawlak K, Timerbaev AR, et al. Metallomics for drug development: a further insight into intracellular activation chemistry of a ruthenium(III)based anticancer drug gained using a multidimensional analytical approach. Metallomics. 2014;6(1):147-53.

20. Matczuk M, Kupiec M, Legat J, Pawlak K, Timerbaev AR, Jarosz M. Use of high-performance liquid chromatography-tandem electrospray ionization mass spectrometry to assess the speciation of a ruthenium(III) anticancer drug in the cytosol of cancer cells. Anal Bioanal Chem. 2015;407(16):4857-62.

21. Timerbaev AR, Keppler BK. Capillary electrophoresis of metalbased drugs. Anal Biochem. 2007;369(1):1-7.

22. Timerbaev AR, Foteeva LS, Pawlak K, Jarosz M. Metallo(proteo)mic studies by capillary electrophoresis using separation capillary as a reactor. Metallomics. 2011;3(8):761-4.

23. Kane-Maguire NAP, Wheeler JF. Photoredox behavior and chiral discrimination of DNA bound $\mathrm{M}(\text { diimine })^{3 \mathrm{n}+}$ complexes $(\mathrm{M}=$ $\mathrm{Ru}^{2+}, \mathrm{Cr}^{3+}$ ). Coord Chem Rev. 2001;211(1):145-62.

24. Schaeper JP, Nelsen LA, Alyson Shupe M, Herbert BJ, KaneMaguire NAP, Wheeler JF. Capillary electrophoresis as a probe of enantiospecific interactions between photoactive transition metal complexes and DNA. Electrophoresis. 2003;24(15):2704-10.

25. Jarosz M, Matczuk M, Pawlak K, Timerbaev AR. Molecular mass spectrometry in metallodrug development: a case of mapping transferrin-mediated transformations for a ruthenium(III) anticancer drug. Anal Chim Acta. 2014;851:72-7.

26. Brouwers EEM, Tibben MM, Rosing H, Schellens JHM, Beijnen JH. Determination of ruthenium originating from the investigational anti-cancer drug NAMI-A in human plasma ultrafiltrate, plasma, and urine by inductively coupled plasma mass spectrometry. Rapid Commun Mass Spectrom. 2007;21(9):1521-30. 